\title{
PERBANDINGAN ANALISIS STRUKTUR GEDUNG FAKULTAS PSIKOLOGI USM (EMPAT LANTAI GEDUNG T) MENGGUNAKAN SNI GEMPA 03-1726-2002 DENGAN SNI GEMPA 03-1726-2012
}

\author{
Bambang Purnijanto ${ }^{1}$, Mukti Wiwoho ${ }^{2}$, dan Ngudi Hari Crista ${ }^{3}$ \\ ${ }^{1)}$ Jurusan Teknik Sipil Universitas Semarang \\ ${ }^{2)}$ Jurusan Teknik Sipil Universitas Semarang \\ ${ }^{3)}$ Jurusan Teknik Sipil Universitas Semarang
}

\begin{abstract}
Abstrak Peraturan perencanaan struktur gedung tahan gempa di Indonesia mengalami perkembangan, maka SNI 03-1726-2002 direvisi menjadi SNI03-1726-2012. Oleh sebab suatu peraturan gempa terbaru muncul dan diberlakukan, maka hal tersebut mengakibatkan perlunya revisi atau peninjauan ulang bangunan-bangunan yang sudah berdiri untuk dikaji ulang menggunakan peraturan terbaru. Masalah yang akan ditinjau adalah besar perbedaan gaya gempa yang terjadi antara SNI 03-1726-2002 dengan RSNI 03-1726-2012, dan bagaimana perilaku struktur bangunan jika dikenakan beban gempa berdasarkan SNI 03-1726-2002 dengan RSNI 03-1726-2012. Batasan masalah penelitian ini adalah bangunan gedung yang akan dikaji gedung kuliah Fakultas Psikologi Universitas Semarang (empat lantai Gedung T); gaya dalam yang ditinjau adalah peningkatan gaya gempa yang terjadi berdasarkan SNI 03-1726-2002 dengan SNI 03-1726-2012; kebutuhan tulangan yang dianalisis adalah tulangan lentur dan tulangan geser pada frame balok dan kolom As-B, dan pemodelan struktur menggunakan bantuan program SAP 2000 versi 14. Penelitian bertujuan untuk: 1)_mendapatkan perbandingan periode getar struktur pada bangunan gedung perkuliahan Fakultas Psikologi USM pada gedung T; 2)_mengetahui gaya geser dasar (base shear) berdasarkan SNI 031726-2002 dengan SNI 03-1726-2012; 3)_mengetahui persentase peningkatan gaya gempa antara SNI 03-1726-2002 dengan SNI 03-1726-2012; dan 4)_mendapatkan kebutuhan tulangan lentur dan geser pada balok dan kolom As -B. Metode yang digunakan dalam penelitian ini adalah simulasi komputasi dengan SAP 2000 versi 14 untuk mendapatkan perbandingan gaya gempa yang terjadi antara SNI Gempa 03-1726-2002 dengan SNI Gempa 03-1726-2012. Simulasi komputasi ini dilakukan dengan memodelkan bentuk bangunan 3 dimensi dengan SAP 2000 versi 14 dari model bangunan gedung T USM.
\end{abstract}

Kata kunci: struktur, gempa, SNI 1726-2002, SNI 1726-2012, analisis struktur, momen, gaya geser, model, komputasi, SAP 2000

\section{Abstract}




\section{Pendahuluan}

Berbagai desain dan arsitektur modern banyak dijumpai di berbagai daerah. Kota Semarang saat ini banyak mengembangkan konstruksi khususnya bangunan gedung. Sejalan dengan pengembangan tersebut maka desain dan perencanaan harus diperhatikan baik dari segi struktur, arsitektur, mekanikal elektrikal serta amdalnya. Indonesia menempati zona tektonik yang sangat aktif karena tiga lempeng besar dunia dan sembilan lempeng kecil lainnya saling bertemu di wilayah Indonesia dan membentuk jalur-jalur pertemuan lempeng yang kompleks (Bird, 2003).

Setelah dilakukan kajian yang mendalam tentang kegempaan, bahwa gempa besar yang terjadi ternyata percepatan batuan dasar lebih besar daripada percepatan batuan dasar yang telah ditetapkan dalam peta gempa SNI 03-1726-2002. Berdasarkan penemuan tersebut menyebabkan peta gempa SNI 03-1726-2002 dinilai sudah tidak sesuai lagi diaplikasikan sebagai pedoman perencanaan struktur tahan gempa (Meilano, 2010).

Permasalahan yang akan ditinjau pada penelitian ini adalah seberapa besar perbedaan gaya gempa yang terjadi antara SNI 03-1726-2002 dengan RSNI 03-1726-2012 dan bagaimana perilaku struktur bangunan jika dikenakan beban gempa berdasarkan SNI 03-1726-2002 dengan RSNI 03-1726-2012. Penelitian dibatasi pada hal-hal sebagai berikut: (1) bangunan gedung yang akan dikaji gedung kuliah Fakultas Psikologi Universitas Semarang (empat lantai Gedung T); (2)gaya dalam yang ditinjau adalah peningkatan gaya gempa yang terjadi berdasarkan SNI 03-1726-2002 dengan SNI 03-1726-2012; (3) kebutuhan tulangan yang dianalisis adalah tulangan lentur dan tulangan geser pada frame balok dan kolom As-B; dan (4) pemodelan struktur menggunakan bantuan program SAP 2000 versi 14.

Penelitian ini bertujuan untuk: (1) mendapatkan perbandingan periode getar struktur pada bangunan gedung perkuliahan Fakultas Psikologi USM; (2) mengetahui gaya geser dasar (base shear) berdasarkan SNI 03-1726-2002 dengan SNI 03-1726-2012; (3) mengetahui persentase peningkatan gaya gempa antara SNI 03-1726-2002 dengan SNI 031726-2012; dan (4) mendapatkan kebutuhan tulangan lentur dan geser pada balok dan kolom As -B.

\section{Kajian Pustaka}

Struktur dimodelkan sebagai struktur frame 3 dimensi. Sistem struktur berbentuk rangka (frame structure), merupakan struktur yang paling banyak digunakan di bidang rekayasa struktur. Pertimbangan yang mendasar dari penggunaan sistem rangka sebagai sistem struktur adalah masalah efisiensi dari pemanfaatan dan penggunaan bahan. Suatu sistem struktur yang berbentuk rangka dapat tersusun dari satu jenis elemen, atau tersusun oleh kombinasi dari sejumlah elemen dengan karakteristik yang berbeda (Indarto, 2005).

Secara umum, desain penulangan dari seluruh elemen struktur didasarkan pada kombinasi pembebanan adalah 1.2DL $+1.6 \mathrm{LL}$. Kombinasi beban untuk metoda ultimit, struktur,komponen elemen struktur dan elemen-elemen pondasi harus dirancang sedemikian hingga kuat rencananya sama atau melebihi pengaruh beban-beban terfaktor.

Struktur teknik sipil pada umumnya didesain berdasarkan kriteria kekakuan (stiffness) dan kriteria kekuatan (strength). Kriteria kekakuan adalah kriteria desain dengan cara 
membatasi terjadinya perubahan bentuk (deformation) yang berlebihan pada struktur akibat pembebanan. Sedangkan kriteria kekuatan adalah kriteria desain dengan cara membatasi terjadinya tegangan-tegangan yang berlebihan pada elemen-elemen struktur (Indarto, 2005).

Dipohusodo (1994) menyatakan bahwa material utama yang digunakan pada struktur gedung ini adalah material beton bertulang. Elemen-elemen dari struktur beton bersifat monolit, sehingga struktur ini mempunyai perilaku yang baik di dalam memikul beban gempa.

\section{Metode Penelitian}

Metode yang digunakan dalam penelitian ini adalah simulasi komputasi dengan program Structural Analysis Programme (SAP 2000) versi 14 untuk mendapatkan perbandingan gaya gempa yang terjadi antara SNI Gempa 03-1726-2002 dengan SNI Gempa 03-1726-2012. Simulasi komputasi ini dilakukan dengan memodelkan bentuk bangunan 3 dimensi dengan SAP 2000 versi 14 dari model bangunan gedung T USM.

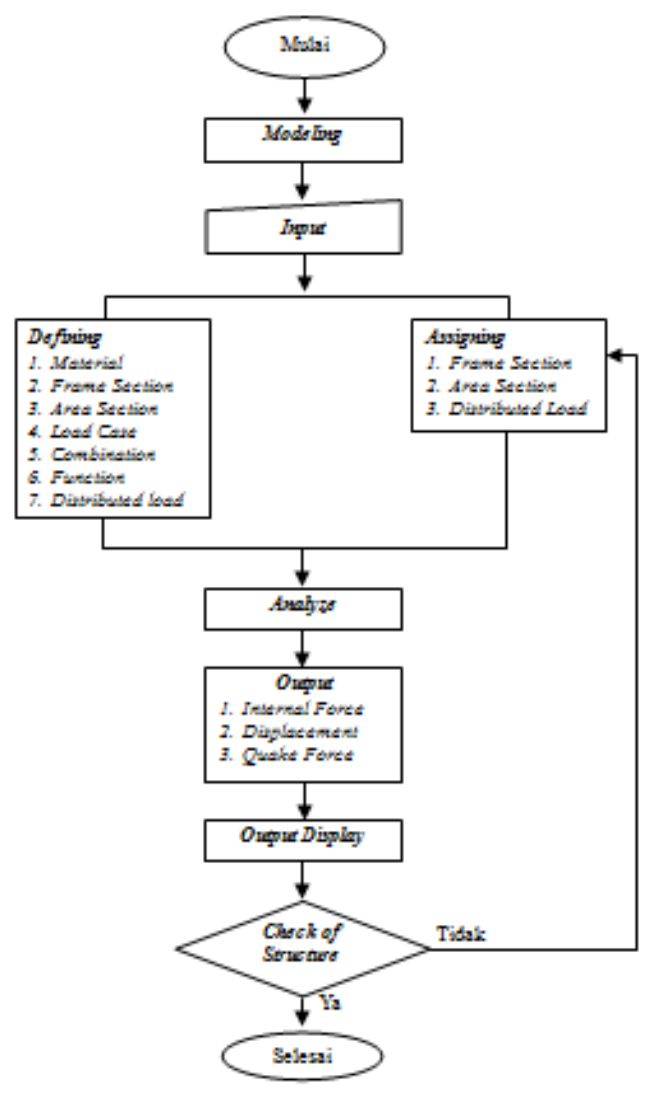

Gambar.1 Alur penyelesaian analisis struktur

Dalam simulasi komputasi untuk bangunan gedung dimodelkan dengan metode elemen hingga, yang merupakan kumpulan elemen-elemen solid tiga dimensi yang satu sama lainnya terkoneksi dengan frame, shell, node atau joint sehingga menjadi struktur 
yang menyatu dan monolit sebagai model bangunan seperti ditunjukkan pada Gambar 2 dan Gambar 3.

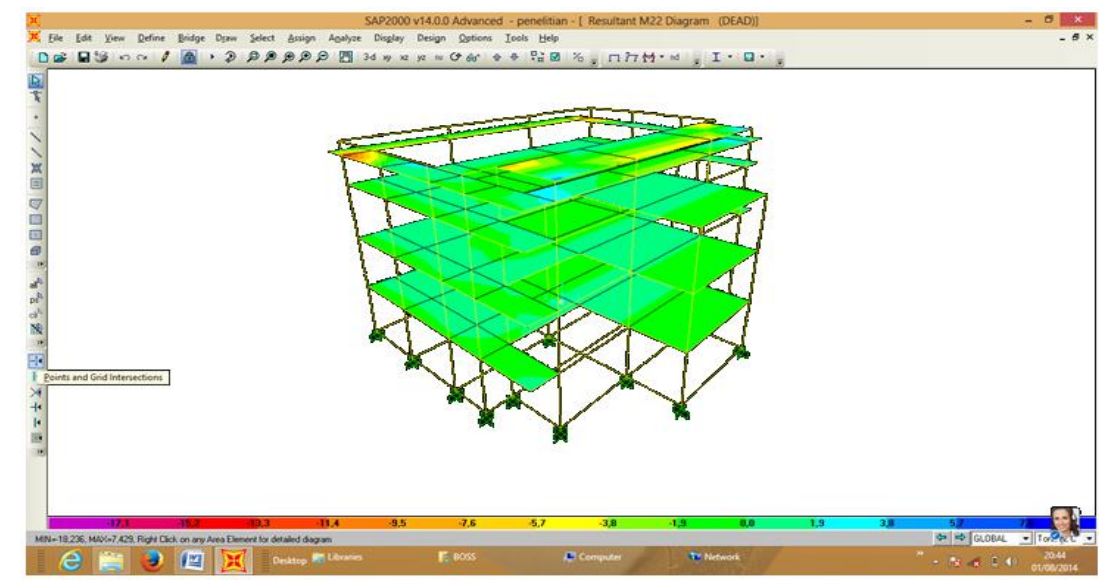

Sumber: Data primer (2015)

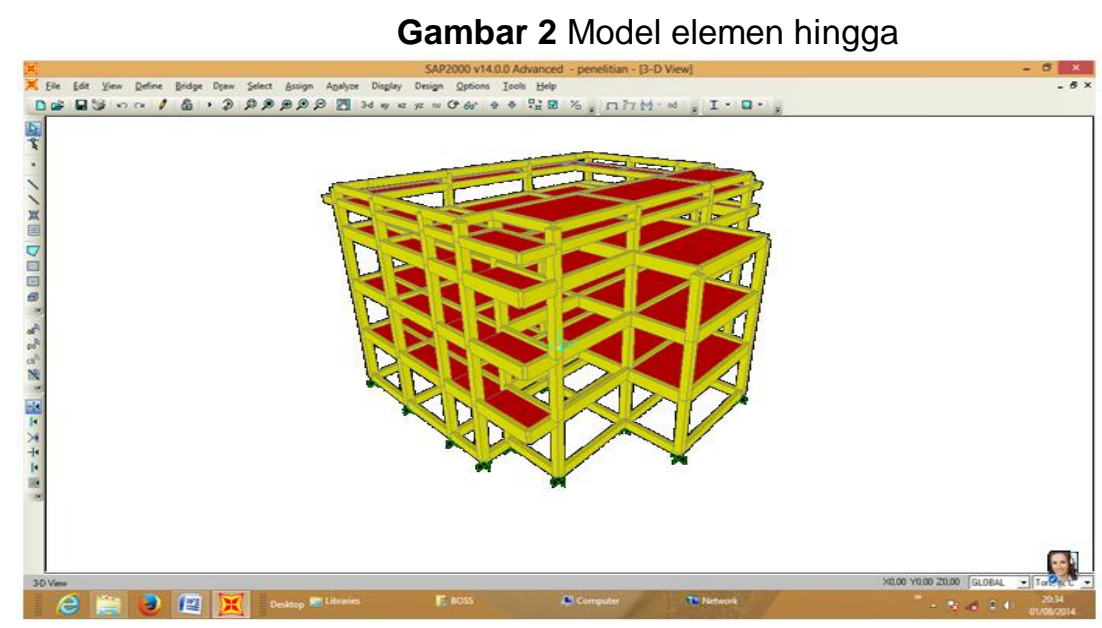

Sumber: Data primer (2015)

Gambar 3 Model stuktur bangunan gedung

Pemilihan sampel untuk mengetahui keluaran dari kebutuhan tulangan lentur dan geser pada balok dan kolom As -B didasarkan pada pertimbangan bahwa balok dan kolom tersebut memiliki bentang dan tinggi yang paling besar (Gambar 4).

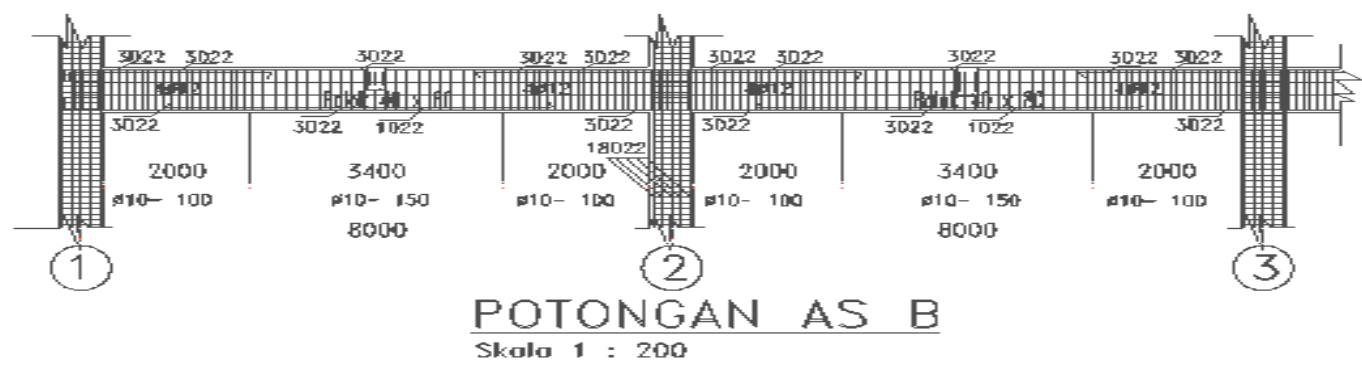

Sumber: Data primer (2015)

Gambar 4 Potongan balok As B 


\section{Hasil dan Pembahasan}

Konfigurasi dari denah bangunan, material struktur dan bentuk atau sistem struktur dari struktur bangunan gedung tahan gempa, harus ditentukan terlebih dahulu pada tahap awal dari perencanaan (preliminary design). Pemilihan ini akan mempengaruhi tahap selanjutnya dari prosedur perencanaan struktur bangunan tahan gempa, sehingga didapatkan sistem struktur yang ekonomis dan cukup aman terhadap pengaruh bebanbeban yang bekerja selama umur rencananya (Indarto, 2005).

Bangunan gedung dimodelkan dengan metode elemen hingga, yang merupakan kumpulan elemen-elemen solid tiga dimensi yang satu sama lainnya terkoneksi dengan frame, shell, dan node atau joint sehingga menjadi struktur yang menyatu.

Untuk menentukan pengaruh Gempa Rencana pada struktur gedung, masing-masing Wilayah Gempa ditetapkan Spektrum Respons Gempa Rencana C-T seperti ditunjukkan dalam Gambar 5 yang disesuaikan dengan percepatan gempa sesuai pembagian zona tahun 2012

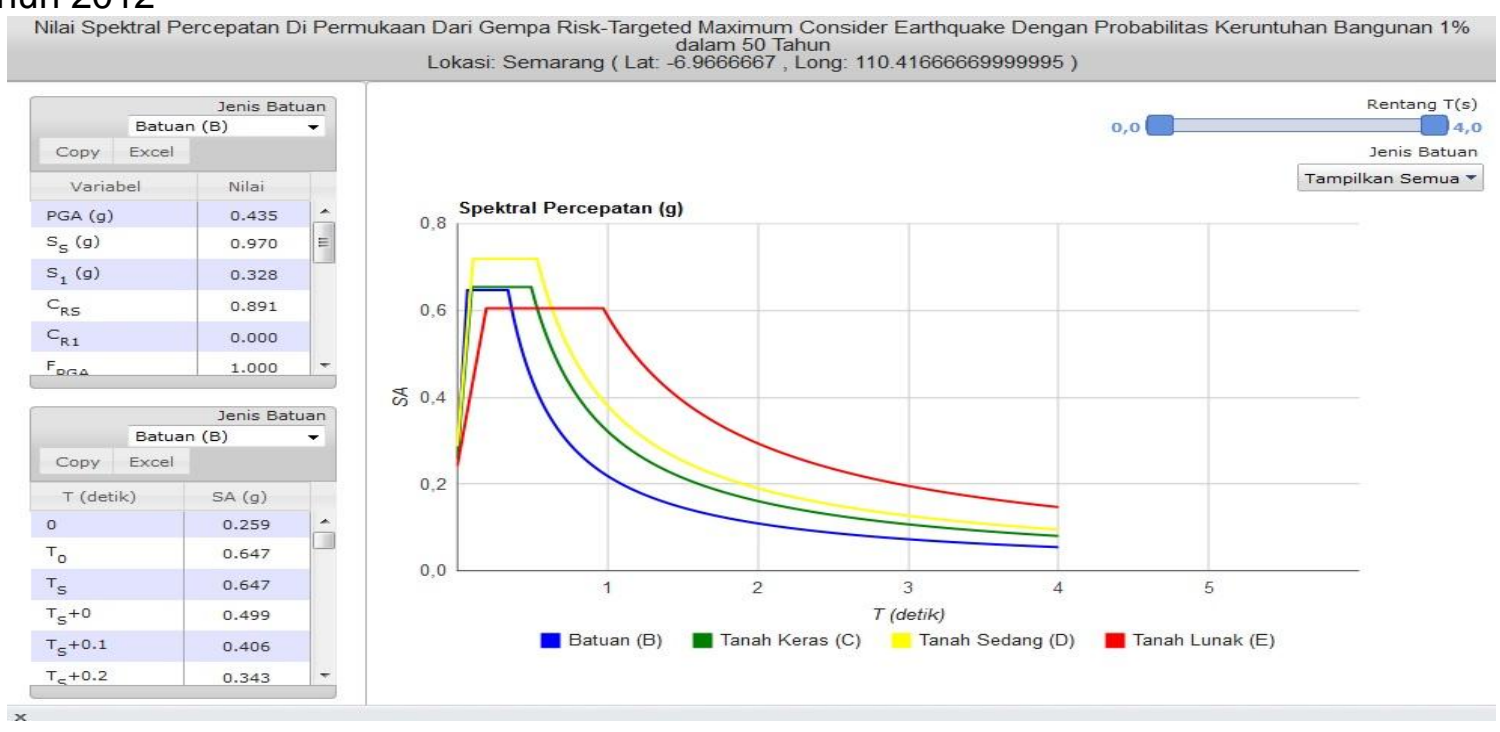

Sumber: Anonim (2015)

Gambar 5 Nilai Spektra Percepatan Wilayah Semarang

Dari hasil simulasi komputasi yang dilakukan dengan memodelkan SAP2000 versi 14 konfigurasi tiga dimensi dari model bangunan Gedung T Fakultas Psikologi USM didapat seperti yang ditunjukkan pada Gambar 6 - Gambar 10.

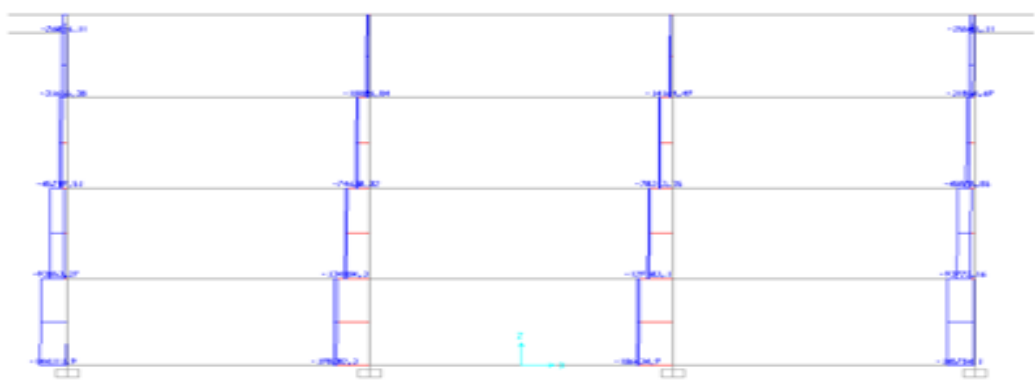

Sumber: Data primer (2015)

Gambar 6 Diagram Gaya axial/Gaya Normal pada as B (Gaya Normal 141,57 ton) 


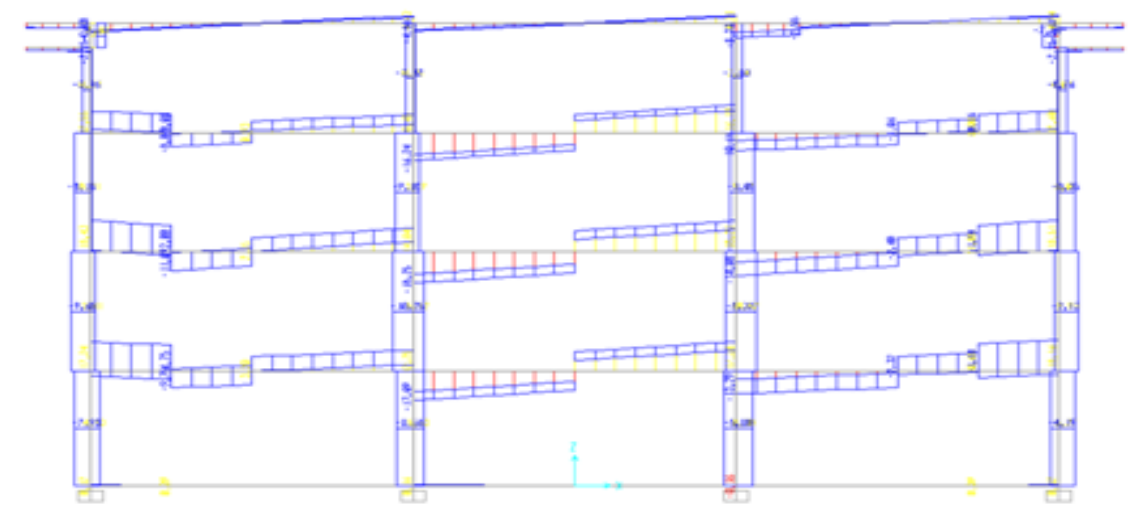

Sumber: Data primer (2015)

Gambar 7 Diagram Gaya Geser pada as B (Gaya geser 17,09 ton)

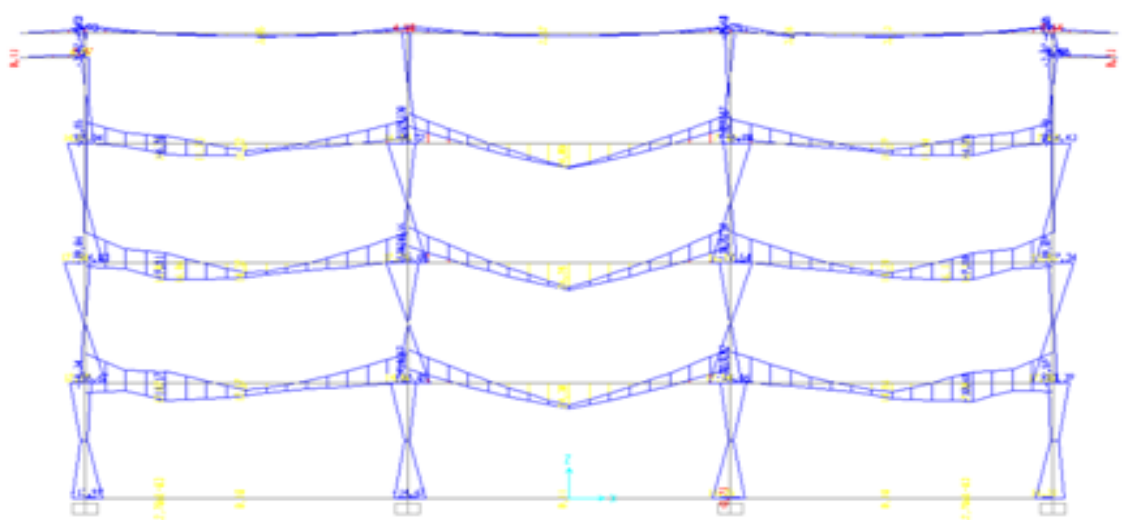

Sumber: Data primer (2015)

Gambar 8 Diagram Momen pada as B (Momen 34,38 ton.m)

\section{Gaya Dalam dari Disain Gempa SNI 1726-2002}

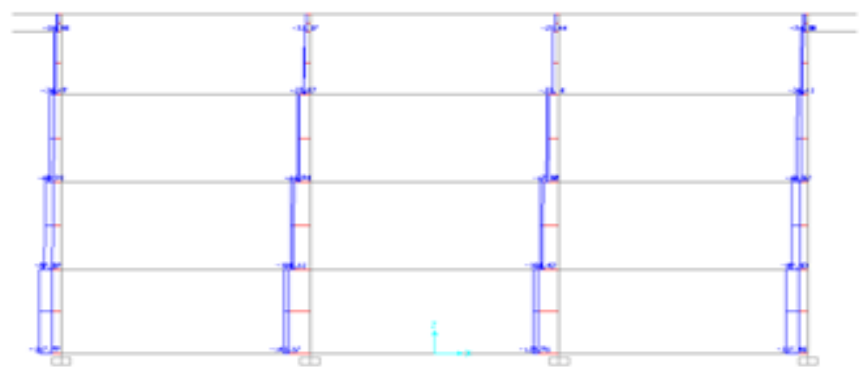

Sumber: Data primer (2015)

Gambar 9 Diagram Gaya Axial/Gaya normal pada as B 
(Gaya Axial/Normal 190,82 ton)

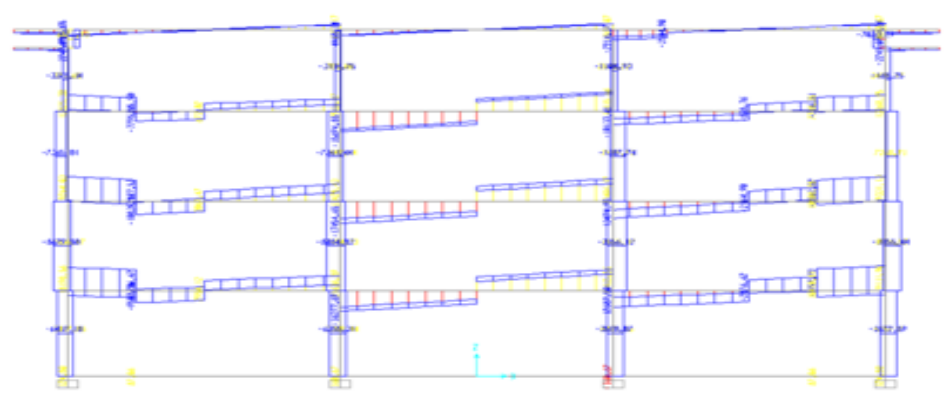

Sumber: Data primer (2015)

Gambar 10 Diagram Gaya Geser pada as B (Gaya Geser 16,27 ton )

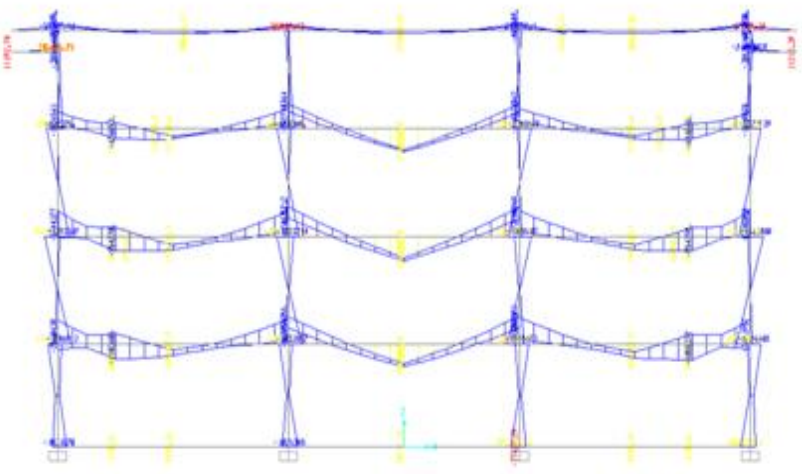

Sumber: Data primer (2015)

Gambar 11 Diagram Momen pada as B (Momen 24,68 ton.m)

Perbandingan Gaya Dalam dari Disain Gempa SNI 1726-2002 dengan Disain SNI 17262012

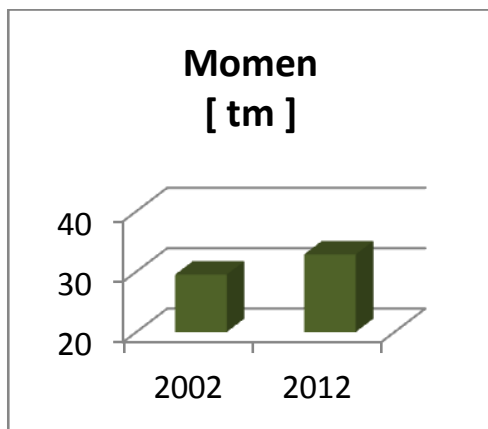

$11,35 \%$

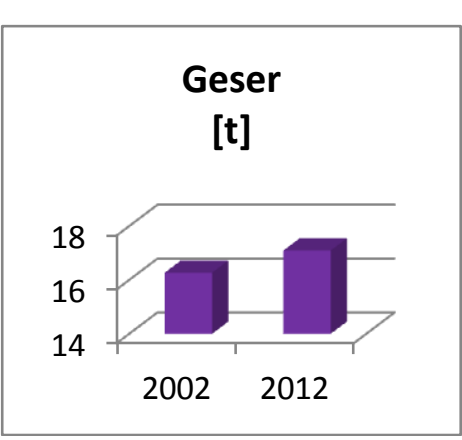

$5,04 \%$
Normal Kolom

[t]

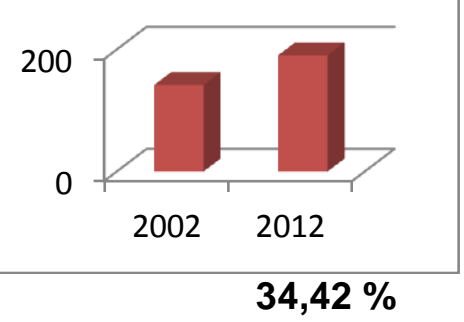

Gambar 12 Diagram peningkatan gaya dalam persentase 


\section{Kebutuhan Tulangan Berdasarkan Disain SNI 03-1726-2002}

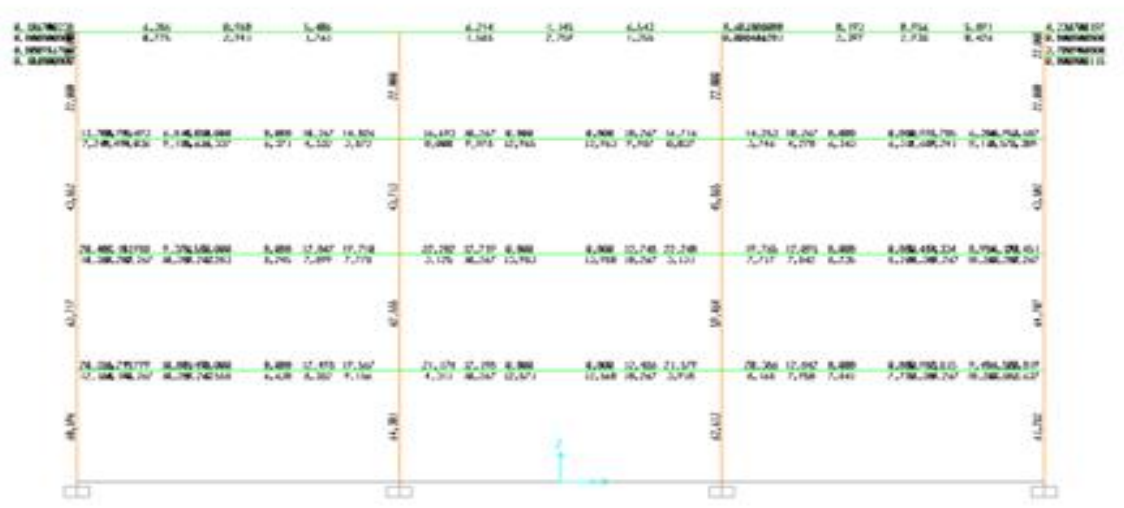

Sumber: Data primer (2015)

Gambar 13 Kebutuhan Tulangan Portal As B

Tulangan kolom $64,301 \mathrm{~cm}^{2}$

Tulangan balok tumpuan $21,174 \mathrm{~cm}^{2}$

Tulangan balok lapangan 12,560 $\mathrm{cm}^{2}$

\section{Kebutuhan Tulangan Berdasarkan Disain SNI 1726- 2012}

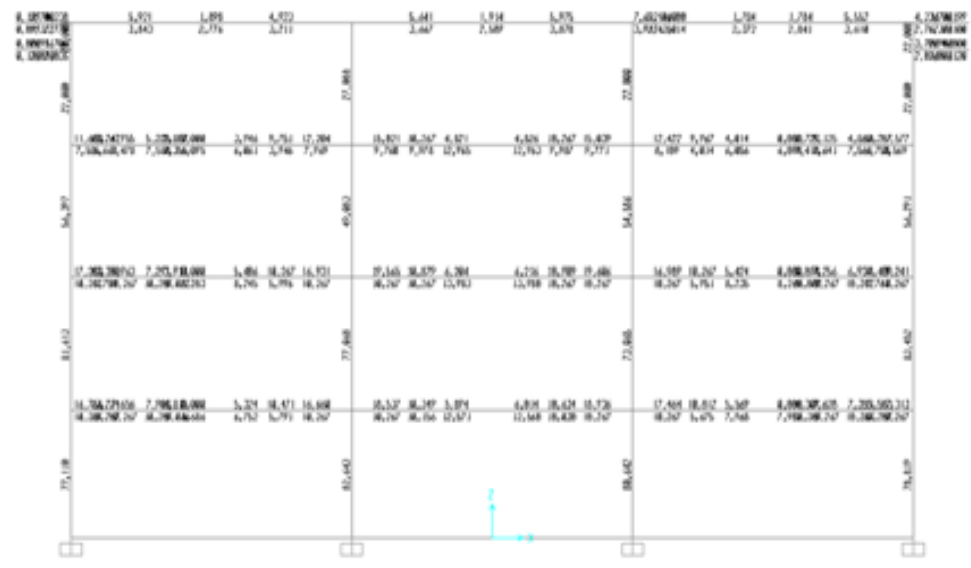

Sumber: Data primer (2015)

Gambar 14 Kebutuhan Tulangan Portal As B

Tulangan kolom $82,643 \mathrm{~cm}^{2}$ eq-y; tulangan balok tumpuan $18,537 \mathrm{~cm}^{2}$-eq-x Tulangan balok lapangan $12,560 \mathrm{~cm}^{2}$; 


\section{Perbandingan Kebutuhan Tulangan}

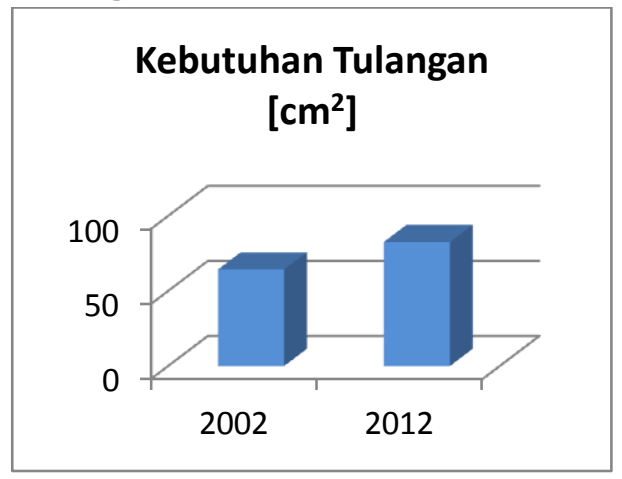

$28,46 \%$

Gambar 15 Diagram Peningkatan Kebutuhan Tulangan dalam Persen

\section{Perbandingan Tulangan Terpasang}

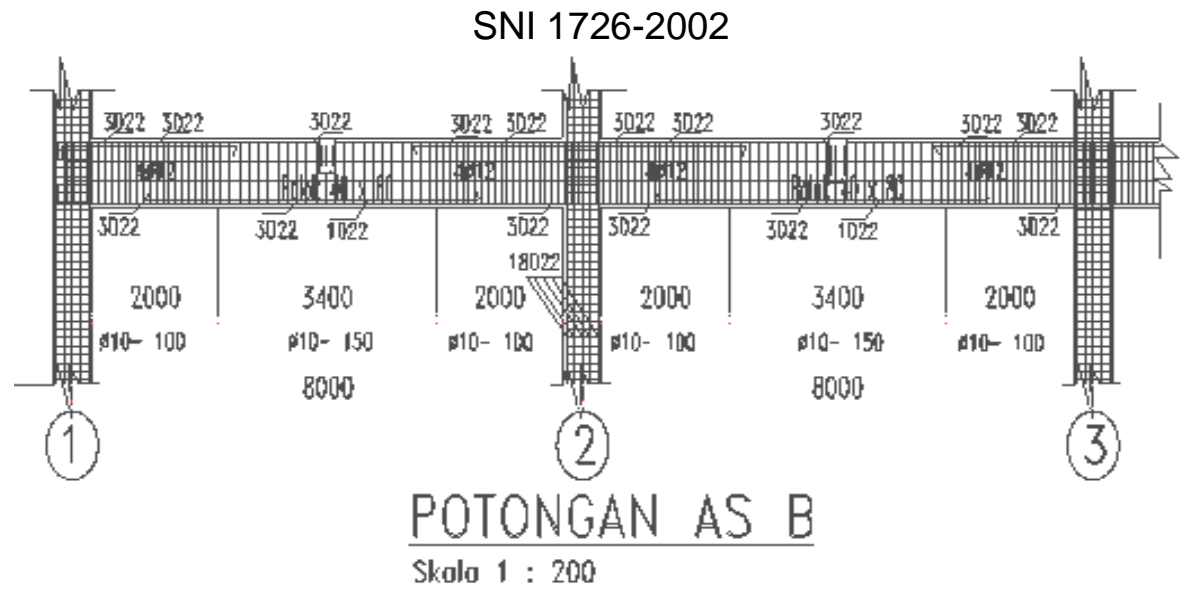

Gambar 16 Tulangan terpasang disain SNI 1726-2002

SNI 1726-2012

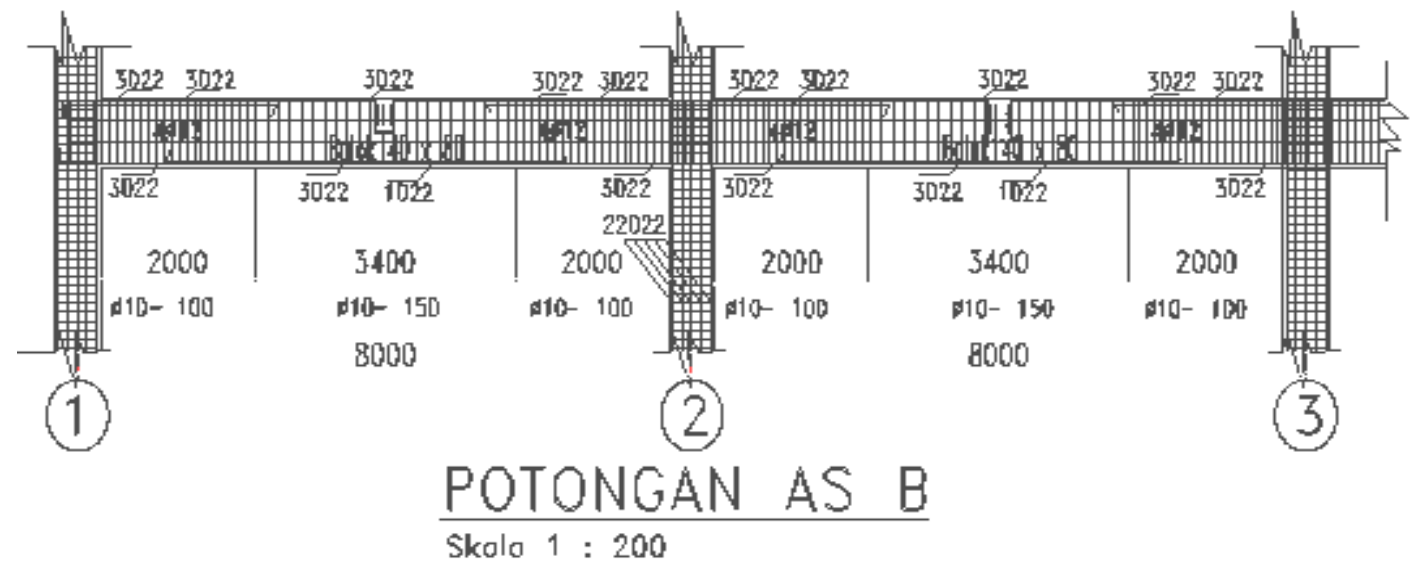

Gambar 17 Tulangan terpasang disain SNI 1726-2012 
Detailing Struktur Rangka Pemikul Momen Khusus

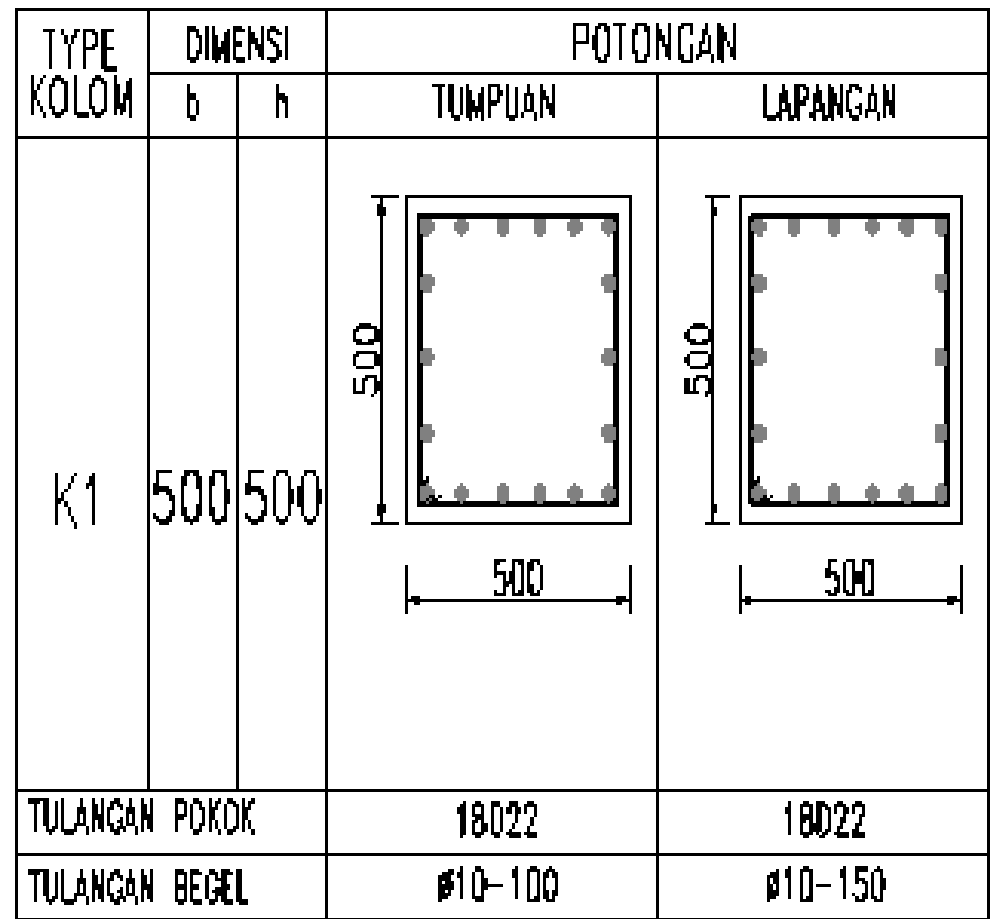

Gambar 18 Detailing struktur rangka pemikul momen khusus disain SNI 1726-2002

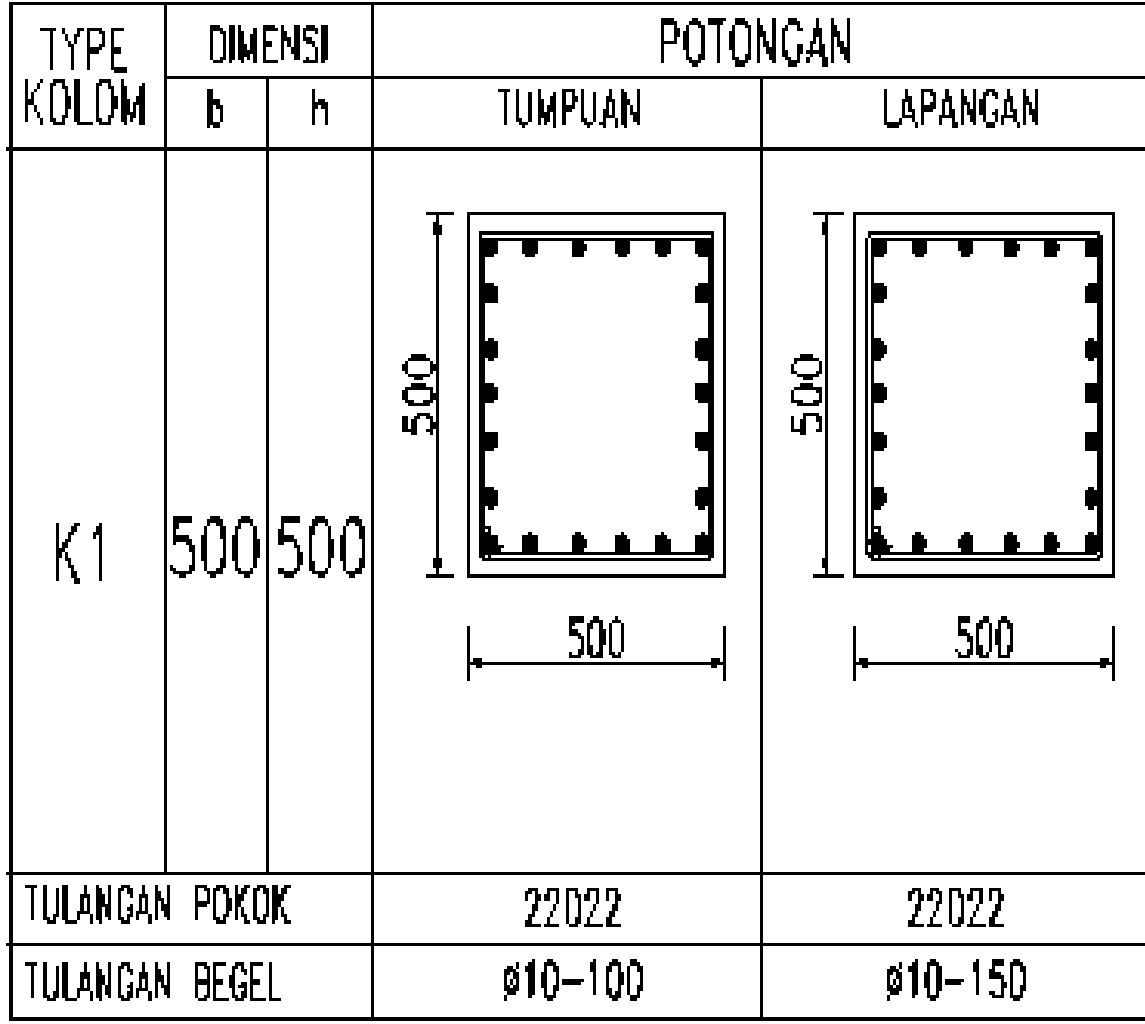

Gambar 19 Detailing struktur rangka pemikul momen khusus disain SNI 1726-2012 


\section{Kesimpulan}

Dari hasil analisis terhadap struktur Gedung T Fakultas Psikologi Universitas

Semarang menggunakan peranti lunak SAP2000 memberikan hasil sebagai berikut:

1) kenaikan momen pada struktur yang didisain menggunakan SNI 1726-2002 terhadap SNI $1726-2012$ senilai $11,35 \%$

2) kenaikan gaya geser pada struktur yang didisain menggunakan SNI 1726-2002 terhadap SNI $1726-2012$ senilai $5,04 \%$

3) kenaikan gaya normal pada struktur yang didisain menggunakan SNI 1726-2002 terhadap SNI 1726-2012 senilai 34,42\%

4) kenaikan kebutuhan tulangan pada struktur yang didisain menggunakan SNI 1726-2002 terhadap SNI 1726-2012 senilai $28,46 \%$

\section{Daftar Pustaka}

Anonim. 2015. Desain Spektra Indonesia. http://puskim.pu.go.id/Aplikasi/desain spektra indonesia_2011/

ASCE, 2010, ASCE Standard ASCE/SEI 7-10, Minimum design loads for buildings and other structures. ASCE.

Badan Standar Nasional , 2002, SNI-03-2847-2002, Tata Cara Perencanaan Ketahanan Gempa untuk Struktur Bangunan Gedung dan Non Gedung. Jakarta: Badan Standarisasi Nasional.

Badan Standar Nasional, 2012, SNI 1726:2012, Tata Cara Perencanaan Ketahanan Gempa untuk Struktur Bangunan Gedung dan Non Gedung. Jakarta: Badan Standarisasi Nasional.

Badan Standar Nasional, 2002, SNI 03-3847-2002 Tata Cara Perhitungan Struktur Beron untuk Bangunan Gedung. Bandung: Badan Standarisasi Nasional.

Bird, P., 2003, An updated digital model of plate boundaries: Geochemistry, Geophysics, Geosystems, vol. 4, no. 3, 1027, doi:10.1029/2001GC000252, (http://element.ess.ucla.edu/publications/2003 PB2002/2001GC000252.pdf).

Dipohusodo, I., 1994, Struktur Beton Bertulang. Jakarta: Gramedia Pustaka Utama

Indarto,H., 2005, Buku Ajar Mekanika Getaran dan Rekayasa Gempa . Semarang: Jurusan Teknik Sipil Universitas Diponegoro.

Indarto, H., Tri Cahyo, H.Adiputra, Kukuh., 2013, Aplikasi SNI Gempa 1726:2012 for Dummies (Handout shortcouse). Semarang: Teknik Sipil UNNES.

Meilano, I. et al. 2010. Pergeseran Koseismik dari Gempa Bumi Jawa Barat. Jurnal Lingkungan dan Bencana Geologi, Vol. 1 No. 1 April 2010 : 35-42. ISSN 2086-7794

Pramono, Hadi \& Rekan, 2001. Desain Konstruksi Plat dan Rangka Beton Bertulang dengan SAP 2000 Versi 9, Yogyakarta: Penerbit Andi 